\title{
PENGARUH MODERNISASI SISTEM ADMINISTRASI PERPAJAKAN \\ TERHADAP KEPATUHAN WAJIB PAJAK ORANG PRIBADI PADA KANTOR PELAYANAN PAJAK (KPP) PRATAMA MADIUN
}

\author{
Diah Sulistia Arini dan Isharijadi \\ Program Studi Pendidikan Akuntansi-FPIPS \\ IKIP PGRI MADIUN
}

\begin{abstract}
ABSTRAK
Penelitian ini bertujuan untuk mengetahui pengaruh penerapan Modernisasi Sistem Administrasi Perpajakan yang meliputi; (1) Struktur Organisasi, (2) Business Process dan TIK terhadap Kepatuhan Wajib Pajak Orang Pribadi.Modernisasi Sistem Administrasi diharapkan mampu meningkatkan kepatuhan Wajib Pajak Orang Pribadi untuk memenuhi kewajiban perpajakannya.Teknik pengumpulan data mengunakan observasi, interview, kuesioner dan kepustakaan. Populasi dalam penelitian ini adalah masyarakat di Wilayah Kota Madiun. Teknik pengambilan sampel dalam penelitian ini menggunakan Cluster Sampling (Area Sampling). Jenis data yang digunakan adalah data primer yang menggunakan kuesioner. Analisis data yang digunakan adalah regresi linier berganda, uji t, uji f, dan uji asumsi klasik. Hasil penelitian menunjukkan (1) Bahwa secara simultan menunjukkan Struktur Organisasi (X1), Business Process dan TIK (X2)terhadap Kepatuhan Wajib Pajak Orang Pribadi Pada KPP Pratama Madiun (Y). Berdasarkan hasil analisis terhadap data yang dikumpulkan, maka dapat diambil kesimpulan bahwa Modernisasi Sistem Administrasi Perpajakan yang terdiri dari StrukturOrganisasi, Business Process dan TIKberpengaruh terhadap Kepatuhan Wajib Pajak Orang Pribadi. Petugas KPP Pratama Madiun disarankan untuk terus meningkatkan pelayanan dan memberikan bantuan konsultasi perpajakan kepada wajib pajak dengan tujuan untuk membentuk citra yang positif dalam jangka panjang serta menimbulkan kesan yang baik buat para pelanggan pajak.
\end{abstract}

Kata Kunci : Struktur Organisasi, Business Process dan TIKKepatuhan Wajib Pajak Orang Pribadi.

\section{PENDAHULUAN \\ Latar belakang}

Penerimaan pajak merupakan sumber utama pembiayaan pemerintah dan pembangunan. Pajak bersifat dinamika dan mengikuti perkembangan kehidupan sosial dan ekonomi negara serta masyarakatnya. Perbaikan dan perubahan mendasar dalam segala aspek perpajakan menjadi alasan dilakukannya reformasi perpajakan dari waktu ke waktu, yang berupa penyempurnaan terhadap kebijakan perpajakan dan sistem administrasi perpajakan.

Kepatuhan pajak selalu dikaitkan dengan reformasi perpajakan, dengan adanya modernisasi perpajakan di harapkan mampu meningkatkan kepatuhan wajib pajak untuk memenuhi kewajiban perpajakannya. Tujuan dari penerapan sisitem administrasi perpajakan modern adalah untuk tercapainya sukarela yang tinggi, tercapainya tingkat kepercayaan masyarakat yang tinggi dan mengedepankan aspek pelayanan yang tinggi. Menurut Harry Purwono (2010: 17) beberapa sasaran dari penerapan sistem administrasi perpajakan modern adalah tercapainya tingkat kepatuhan sukarela yang tinggi, tercapainya tingkat kepercayaan masyarakat yang tinggi. Hal mendasar dalam modernisasi pajak adalah terjadinya perubahan paradigma perpajakan, yaitu dari semula berbasis jenis pajak sehingga terkesan ada dikotomi menjadi berbasis fungsi, dan lebih mengedepankan aspek pelayanan kepada masyarakat. Kemudian didukung oleh fungsi pengawasan, pemeriksaan, maupun penagihan pajak. 


\section{Reformasi Administrasi Perpajakan}

Kepatuhan pajak selalu dikaitkan dengan administrasi pajak dimana hal tersebut menjadi salah satu faktor yang mempengaruhi tingkat kepatuhan wajib pajak didalam melaksanakan kewajiban perpajakannya. Reformasi dalam administrasi pajak telah beberapa kali dilakukan. Hal ini didorong oleh kebutuhan pemerintah dalam mencapai target penerimaan negara guna membiayai layanan publik (public services).

\section{Penerapan Administrasi Perpajakan Modern}

Penerapan administrasi perpajakan modern ini merupakan indikasi positif dari pihak pemerintah untuk secara bersama-sama dengan masyarakat Waib Pajak mengelola pajak secara efektif dan efisien.

a. Struktur Organisasi

Struktur organisasi adalah unsur yang berkaitan dengan pola-pola peran yang sudah ditentukan dan hubungan antar peran, alokasi kegiatan kepada sub unit-sub unit terpisah, pendistribusian wewenang diantara posisi administratif, dan jaringan komunikasi formal

b. Business Process dan Teknologi Informasi dan Komunikasi.

Business process merupakan pengawasan yang dilakukan oleh DJP dalam upaya untuk menyederhanakan proses pengawasan serta mempercepat proses pengambilan keptusan secara efisien dan efektif.

\section{HIPOTESIS PENELITIAN}

Berdasarkan masalah pokok yang telah dibahas di atas, maka hipotesisnyadapat dirumuskan sebagai berikut :

H1: Apakah struktur organisasi berpengaruh terhadap kepatuhan wajib pajak orang pribadi?

H2: Apakah business process dan Teknologi Informasi dan Komunikasi berpengaruh terhadap kepatuhan wajib pajak orang pribadi?

H3: Apakah pelaksanaan struktur organisasi, dan business process dan teknologi informasi dan komunikasi, secara simultan berpengaruh terhadap kepatuhan wajib pajak orang pribadi?

\section{METODE PENELITIAN}

\section{Populasi, Sampel dan Teknik pengambilan sampel}

Populasi mempunyai peranan yang sangat penting dalam penelitian karena populasi merupakan sumber data yang akurat yang diperlukan dalam penelitian. Penetapan populasi yang tepat akan mendapatkan sumber data yang benar-benar mampu memberikan informasi yang diperlukan.

(Sugiyono, 2010: 117). Jadi populasi bukan hanya orang, tetapi juga obyek dan benda-benda alam yang lain. Populasi juga bukan sekedar jumlah yang ada pada obyek/subyek yang dipelajari, tetapi meliputi seluruh karakteristik/sifat yang dimiliki oleh subyek atau obyek. Populasi dalam penelitian ini adalah seluruh Wajib Pajak Orang Pribadi Tahun 2013 sejumlah 30.743 orang di Wilayah Kota Madiun yang terdaftar pada Kantor Pelayanan Pajak(KPP)Pratama Madiun.

Sampel sangat penting bagi seorang peneliti, oleh karena itu pengambilan sampel haruslah dilakukan dengan cermat sehingga dapat diperoleh sampel yang benar-benar dapat menggambarkan keadaan populasi yang sebenarnya.

Menurut Sugiyono (2013:118) sampel adalah bagian dari jumlah dan karakteristik yang dimiliki oleh populasi tersebut. Dengan rumus yang dikembangkan oleh Isaac dan Michaeldalam bukunya sugiono. 


$$
\begin{aligned}
& \text { Rumus: } \\
& \mathrm{S}=\frac{\lambda^{2} \cdot \mathrm{N} \cdot \mathrm{P} \cdot \mathrm{Q}}{d^{2}(\mathrm{~N}-1)+\lambda^{2}}
\end{aligned}
$$

Dimana :

$\lambda^{2}=$ Chi kuadrat dan tingkat kesalahan $5 \%=3,841$.

$\mathrm{N} \quad=$ Jumlah populasi.

$\mathrm{P}=\mathrm{Q} \quad=$ Peluang benar dan salah $(0,5)$.

$\mathrm{d}=$ Perbedaan antara rata-rata sampel dengan rata-rata populasiadalah 0,10 .

$\mathrm{S}=\frac{\lambda^{2} \cdot \mathrm{N} \cdot \mathrm{P} \cdot \mathrm{Q}}{d^{2}(\mathrm{~N}-1)+\lambda^{2}}$

$\mathrm{S}=\frac{3,841 \times 30.743 \times 0,5 \times 0,5}{0,05^{2}(30.743-1)+3,841}$

$S=\frac{29521}{76,85+3,841}$

$\mathrm{S}=\frac{29521}{80.691}$

$S=366$

Berdasarkan jumlah populasi yang telah diketahui dari perhitungan rumus diatas, maka jumlah sampel yang dibutuhkan sebanyak 366 wajib pajak. 366/3 = 122 orang / Kec. Wilayah Kota Madiun.

\begin{tabular}{ccc}
\hline Kec. Taman & Kec. Manguharjo & Kec. Kartoharjo \\
\hline 122 & 122 & 122 \\
\hline
\end{tabular}

Menurut Sugiyono (2010: 121-122) Teknik pengambilan sampel ini menggunakan teknik Nonprobability sampling adalah teknik pengambilan sampel yang tidak memberi peluang/kesempatan sama bagi setiap unsur atau anggota populasi untuk dipilih menjadi sampel. Sedangkan metode pengambilan sampel dilakukan dengan menggunakan Cluster Sampling (Area Sampling) adalah teknik sampling daerah digunakan untuk menentukan sampel bila obyek yang akan diteliti atau sumber data sangat luas, misal penduduk dari suatu negara, propinsi atau kabupaten.

\section{Teknik Analisis Data}

Dalam penelitian ini metode analisis data menggunakan analisis deskriptif melalui hasil nilai indeks dan nilai analisis regresi linier berganda melalui hasil olah data SPSS ( Statistical Package for Social Science) for Windows 19.

\section{Statistik Deskriptif}

Sugiyono (2010: 207) statistik deskriptif adalah statistik yang digunakan untuk menganalisis data dengan cara mendiskripsikan atau menggambarkan data yang telah terkumpul sebagai mana adanya tanpa bermaksud membuat kesimpulan yang yang berlaku untuk umum atau generalisasi.

\section{Uji Instrumen}

Instrumen yang digunakan dalam penelitian ini adalah dengan menggunakan kuesioner. Kuesioner yang baik harus memenuhi dua persyaratan yaitu valid dan reliable. 
a. Uji Validitas

Menurut Duwi Priyatno (2010: 14) uji validitas adalah pengujian yang dilakukan guna untuk mengetahui seberapa cermat suatu instrumen dengan mengukur apa yang ingin diukur.

b. Uji Reliabilitas

MenurutImam Gozali (2011: 47) reliabilitas adalah alat ukur suatu kuesioner yang merupakan indikator dari variabel atau konstruk. Suatu kuesioner dikatakan reliabel atau handal jika jawaban seseorang terhadap pernyataan adalah konsisten atau stabil dari waktu ke waktu.

\section{Uji Asumsi Klasik}

Pengujian asumsi klasik dilakukan untuk mengetahui kondisi data yang ada agar dapat menentukan model analisis yang tepat. Untuk menguji apakah persamaan garis regresi yang diperoleh linier dan dapat dipergunakan untuk melakukan peramalan, maka harus dilakukan uji asumsi klasik, yaitu :

a. Uji Normalitas

Uji normalitas betujuan untuk menguji apakah dalam model regresi, variabel penganggu atau residual memiliki distribusi normal. Ada 2 cara untuk mendeteksi apakah residual berdistribusi normal atau tidak yaitu dengan analisis grafik dan uji statistik (Imam Gozali, 2011: 160-161).

b. Uji Autokorelasi

Imam Ghozali (2011: 110-111) berpendapat bahwa: "Uji autokorelasi bertujuan untuk menguji apakah model regresi linier ada korelasi antara kesalahan pengganggu pada periode $t$ dengan kesalahan pengganggu pada periode $t-1$ (sebelumnya).

c. Uji Heteroskedastisitas

Duwi Priyatno (2010: 67) berpendapat bahwa: "Uji heteroskedastisitas adalah keadaan dimana terjadinya ketidaksamaan varian dari residual pada model regresi. Model regresi yang baik mensyaratkan tidak adanya masalah heteroskedastisitas. Untuk mendeteksi ada tidaknya heteroskedastisitas ada beberapa metode, antar lain dengan cara uji Spearman's rho, uji park, uji Glejser, dan dengan melihat pola titik-titik pada scatterplots regresi.

d. Uji Multikolinearitas

Imam Ghozali (2011: 105) berpendapat bahwa: "Uji multikolinearitas bertujuan untuk menguji apakah model regresi ditemukan adanya korelasi antar variabel bebas (independent)".Selain itu multikolinearitas dapat digunakan VIF (Variance Inflation Factor) yang dihitung dengan rumus sebagai berikut:

$$
\text { VIF }=1 / \text { Tolerance }
$$

\section{Pengujian Model}

Analisis Regresi Linier Berganda

Digunakan untuk mengetahui pengaruh variabel independen yaitu struktur organisasi $\left(\mathrm{X}_{1}\right)$, business process dan TIK $\left(\mathrm{X}_{2}\right)$ terhadap variabel dependen yaitu kepatuhan wajib pajak (Y). Persamaan regresi dalam penelitian ini adalah:

\section{Uji Hipotesis}

$$
\mathrm{Y}=\mathrm{a}+\mathrm{b}_{1} \mathrm{X}_{1}+\mathrm{b}_{2} \mathrm{X}_{2}
$$

Secara statistik diukur melalui nilai koefisien determinasi, nilai statistik $\mathrm{F}$ dan nilai statistik t pada level $5 \%(\alpha=0,05)$. Uji statistik disebut signifikan apabila nilai uji statistiknya berada dalam daerah kritis (daerah dimana $\mathrm{H}_{0}$ ditolak), sebaliknya disebut tidak signifikan bila nilai uji statistiknya berada dalam daerah dimana $\mathrm{H}_{0}$ diterima. 
a. Koefisien Determinasi $\left(\mathrm{R}^{2}\right)$

Imam Ghozali (2012: 97) berpendapat bahwa: "koefisien determinasi ( $\mathrm{R}^{2}$ adjusted) pada intinya untuk mengukur seberapa jauh kemampuan model dalam menerangkan variasi variabel dependen.

b. Uji Statistik t

Duwi Priyatno (2010: 86) berpendapat bahwa : "Uji statistik t digunakan untuk menguji pengaruh variabel independen secara parsial terhadap variabel dependen". Dimana pengambilan keputusan disini yaitu:

1) $\mathrm{t}$ hitung $\leq \mathrm{t}$ tabel atau $\mathrm{t}$ hitung $\geq \mathrm{t}$ tabel maka $\mathrm{H}_{0}$ diterima.

2) thitung $>$ t tabel atau t hitung $<\mathrm{t}$ tabel maka $\mathrm{H}_{0}$ ditolak

3) Jika signifikansi> 0,05 maka $\mathrm{H}_{0}$ diterima, dan jika signifikansi $\leq 0,05$ maka $\mathrm{H}_{0}$ ditolak.

c. Uji Statistik F

Duwi Priyatno (2010: 83) berpendapat bahwa: "Uji Statistik F digunakan untuk menguji pengaruh variabel independen secara bersama-sama terhadap variabel dependen". Dimana pengambilan keputusan disini yaitu:

1) $\mathrm{F}$ hitung $\leq \mathrm{F}$ tabel $\mathrm{H}_{0}$ diterima.

2) t hitung $>$ t tabel $\mathrm{H}_{0}$ ditolak

3) Jika signifikansi $>0,05$ maka $\mathrm{H}_{0}$ diterima, dan jika signifikansi $\leq 0,05$ maka $\mathrm{H}_{0}$ ditolak.

\section{HASIL DAN PEMBAHASAN}

Data yang dianalisis adalah data tentang pemungutan retribusi dan pelayanan mempengaruhi kepuasan pelanggan. Data dianalisis dengan bantuan program microsoft Office Excel dan program statistik komputer SPSS 20.0 for windows.

1. Analisis Statistik Deskriptif

Analisis statistik deskriptif dalam penelitian ini digunakan untuk mengetahui gambaran secara umum data penelitian mengenai variabel-variabel penelitian yang terdiri dari Kepatuhan Wajib Pajak Orang Pribadi (Y) sebagai variabel dependen, Struktur Organisasi (X1), dan Business Process dan TIK (X2) sebagai variabel independennya.Data statistik deskriptif variabel-variabel penelitian yang menunjukkan nilai minimum, maximum, mean dan standar deviation dari masing-masing variabel penelitian dapat dilihat pada tabel di bawah ini:

\section{Tabel Hasil Analisis Statistik Deskriptif}

\begin{tabular}{lccccc}
\hline & $\mathrm{N}$ & Minimum & Maximum & Mean & Std. Deviation \\
\hline $\begin{array}{l}\text { Kepatuhan wajib pajak orang } \\
\text { pribadi(Y) }\end{array}$ & 366 & 8 & 25 & 18,78 & 3,999 \\
Struktur Organisasi(X1) & 366 & 4 & 15 & 10,33 & 2,393 \\
Business Proces dan TIK (X2) & 366 & 5 & 15 & 11,33 & 2,255 \\
Valid N (listwise) & 366 & & & & \\
\hline
\end{tabular}

\section{Sumber: Hasil Pengolahan Data}

2. Uji Instrumen
a. Uji Validitas

Uji validitas digunakan untuk mengukur sah atau valid tidaknya suatu kuesioner (Imam Ghozali, 2012:52). Pengujian validitas menggunakan korelasi bivariat yang dilakukan dengan menghitung korelasi antara skor masing-masing butir pertanyaan dengan total skor variabel dengan kententuan sig $\leq 0,05$ berarti 
valid dan sig> 0,05 berarti tidak valid. Berikut ini hasil uji validitas masing-masing indikator:

Tabel Hasil Uji Validitas

\begin{tabular}{lcc}
\hline \multicolumn{1}{c}{ Variabel } & Sig & Keterangan \\
\hline Struktur Organisasi (X1) & 0,000 & Valid \\
Business Processdan TIK (X2) & 0,000 & Valid \\
Kepatuhan Wajib Pajak(Y) & 0,000 & Valid \\
\hline
\end{tabular}

Sumber : Data diolah dengan IBM SPSS 20, 2011

Berdasarkan table hasil uji validitas dapat diketahui bahwa semua item pertanyaan variabel Struktur Organisasi, Business Process dan TIK dan Kepatuhan Wajib Pajak Orang Pribadi dinyatakan valid karena dari hasil korelasi antara hasil jawaban responden pada tiap item pertanyaan dengan skor total di dapat hasil yang signifikan yaitu nilai sig $<0,05$.

a) Uji Reliabilitas

Uji reliabilitas digunakan untuk menguji konsisten alat ukur, apakah hasilnya tetap konsisten jika pengukuran diulang, apabila nilai cronbach's alpha $(\alpha)$ suatu variabel > 0,60 maka indikator yang digunakan oleh variabel tersebut reliable. Hasil uji reliabilitas dari instrumen dapat dilihat pada tabel berikut :

Tabel Hasil Uji Reliabilitas Variabel Y, X1 dan X2

\begin{tabular}{lcc}
\hline \multicolumn{1}{c}{ Variabel } & Cronbach's Alpha & Keterangan \\
\hline Struktur Organisasi (X1) & $0,866>0,60$ & Reliabel \\
Business Proces dan TIK (X2) & $0,856>0,60$ & Reliabel \\
Kepatuhan Wajib Pajak (Y) & $0,825>0,60$ & Reliabel \\
\hline
\end{tabular}

Sumber: Data diolah dengan SPSS IBM 20,0

Hasil uji reliabilitas pada tabel memperlihatkan nilai cronbach's alpha semua variabel di atas 0,60 sehingga dapat disimpulkan indikator yang digunakan oleh variable Struktur Organisasi, Business Process dan TIK dan Kepatuhan Wajib Pajak Orang Pribadi dipercaya atau handal untuk digunakan sebagai alat ukur variabel.

3. Uji Asumsi Klasik

a. Uji Normalitas

Imam Ghozali (2011: 160) menyatakan bahwa uji normalitas bertujuan untuk menguji apakah dalam model regresi, variabel pengganggu atau residual memiliki distribusi normal. Model regresi yang baik adalah pada nilai residualnya terdistribusi secara normal.Pengujian normalitas data dalam penelitian ini dilakukan dengan menggunakan grafik histogram, grafik normal probability plot dan uji Kolmogorov-Smirnov (Analisis Explore).

1) Analisis Grafik

Pada pengujian grafik histogram dapat melihat bentuk histogramjika data terdistribusi secara normal, maka histogram akan berbentuk seperti lonceng. Pengujian normalitas data dapat juga melihat hasil grafik normalprobability plot dengan ketentuan jika titik-titik data menyebar dan mengikuti garis diagonal maka dapat dikatakan data terdistribusi secara normal. Hasil analisis grafik ditunjukkan pada gambar di bawah ini. 


\section{Gambar Pengujian Normalitas}

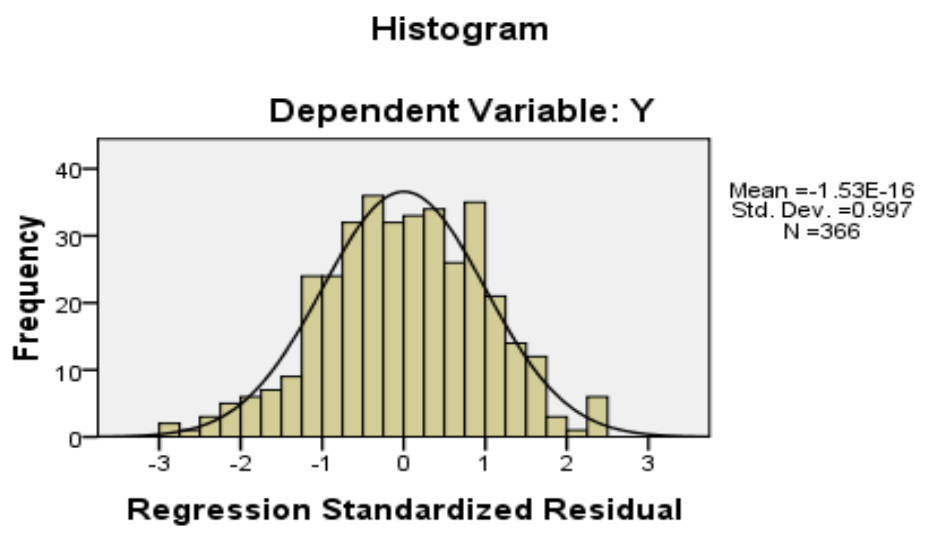

Berdasarkan gambar dapat diketahui bahwa histogram uji normalitas menunjukkan bahwa gambar membentuk lonceng maka dapat disimpulkan data yang digunakan dalam penelitian ini terdistribusi secara normal, sehingga sudah memenuhi asumsi normalitas.

\section{Gambar Pengujian Normalitas}

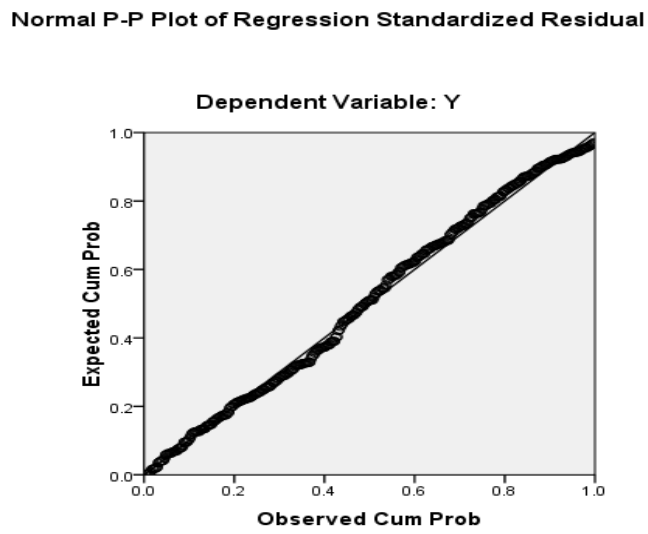

Langkah selanjutnya untuk memperkuat temuan pada uji normalitas histogram maka dilakukan uji normalitas dengan P-Plot.Hasil grafik normal probability plot pada gambar diketahui bahwa titik-titik menyebar dan mengikuti garis diagonal dengan demikian dapat disimpulkan bahwa data terdistribusi secara normal.Jadikedua grafik tersebutmenunjukkan bahwa model regresi layak dipakai karena memenuhi asumsi normalitas.

2) Analisis Statistik

Uji statistik Kolmogorov-Smirnov (K-S) juga dilakukan pada uji normalitas untuk lebih memastikan apakah data residual terdistribusi secara normal atau tidak.Kriteria pengambilan keputusan dalam uji KolmogorovSmirnov (Analisis Explore)yaitu jika signifikansi > 0,05 maka data terdistribusi normal dan jika signifikansi $<0,05$ maka data tidak terdistribusi secara normal. Hasil uji normalitas dengan menggunakan uji Kolmogorov-Smirnov (Analisis Explore) dapatdilihat pada tabel berikut ini. 
Tabel Uji Kolmogorov-Smirnov

One-Sample Kolmogorov-Smirnov Test

\begin{tabular}{llr}
\hline & & Unstandardized Residual \\
\hline Normal Parameters & & 366 \\
& Mean &, 0000000 \\
Most Extreme Differences & Std. Deviation & 3,24227451 \\
& Absolute &, 035 \\
& Positive &, 023 \\
Kolmogorov-Smirnov Z & Negative &,- 035 \\
Asymp. Sig. (2-tailed) & &, 663 \\
\hline a. Test distribution is Normal. &, 771 \\
\hline
\end{tabular}

Berdasarkan hasil pengujian pada tabel 4.10 didapatkan bahwa besarnya nilai Asympotic Significane sebesar 0,771. Nilai tersebut lebih besar dari0,05 $(0,771>0,05)$, sehingga dapat disimpulkan bahwa data dalam penelitian ini telah terdistribusi secara normal dengan kata lain model regresi yang digunakan memenuhi asumsi normalitas.

b. Uji Autokorelasi

Imam Ghozali (2011: 110-111) berpendapat bahwa: "Uji autokorelasi bertujuan untuk menguji apakah model regresi linier ada korelasi antara kesalahan pengganggu pada periode $t$ dengan kesalahan pengganggu pada periode t-1 (sebelumnya)". Autokorelasi muncul karena observasi yang berurutan sepanjang waktu berkaitan satu sama lainnya. Salah satu ukuran dalam menentukan ada tidaknya masalah autokorelasi dengan uji Durbin-Watson (DW).

Keputusan ada atau tidaknya autokorelasi dapat ditentukan dengan melihat posisi nilai DW (Durbin-Watson) yaitu jika nilai DW berada diantara dU $<$ DW $<4$ du maka tidak terjadi autokorelasi.Hasil uji autokorelasi dengan Durbin-Watson dapat dilihat pada tabel berikut ini:

\section{Tabel Hasil Uji Autokorelasi Model Summary ${ }^{\mathrm{b}}$}

\begin{tabular}{lcrrrr}
\hline Model & $\mathrm{R}$ & $\mathrm{R}$ Square & $\begin{array}{c}\text { Adjusted R } \\
\text { Square }\end{array}$ & $\begin{array}{l}\text { Std. Error of } \\
\text { the Estimate }\end{array}$ & Durbin-Watson \\
1 & 0,585 & 0,343 & 0,339 & 3,251 & 2,252 \\
\hline
\end{tabular}

a. Predictors: (Constant), Struktur Organisasi, dan Business Proces dan TIK.

b. Dependent Variable: Kepatuhan Wajib Pajak

Dari Tabel di atas nilai DW 2,252 sedangkan dari tabel DW dengan signifikansi 0,05 dan jumlah data $(\mathrm{n})=366$ serta $\mathrm{k}=4$ diperoleh nilai $\mathrm{dU}=1,84577$ $<\mathrm{DW}=2,252<4$-du $=2,15423$. Jadi dapat disimpulkan bahwa tidak terdapat autokorelasi. 
c. Uji Heteroskedastisitas

Uji heteroskedastisitas bertujuan untuk menguji apakah dalam model regresi terjadi ketidaksamaan variance dari residual satu pengamatan terhadap pengamatan yang lain. Ada tidaknya heteroskedastisitas dapat dideteksi dari gambar Scatterplot.Jika terdapat pola tertentu, seperti titik-titik yang ada membentuk pola tertentu yang teratur (bergelombang,melebar, kemudian menyempit), maka mengindikasikan telah terjadi heteroskedastisitas dan begitu pula sebaliknya.Berdasarkan hasil pengujian SPSS, gambar scatterplot yang terbentuk sebagai berikut:

\section{Gambar 4.3.Pengujian heteroskedastisitas}

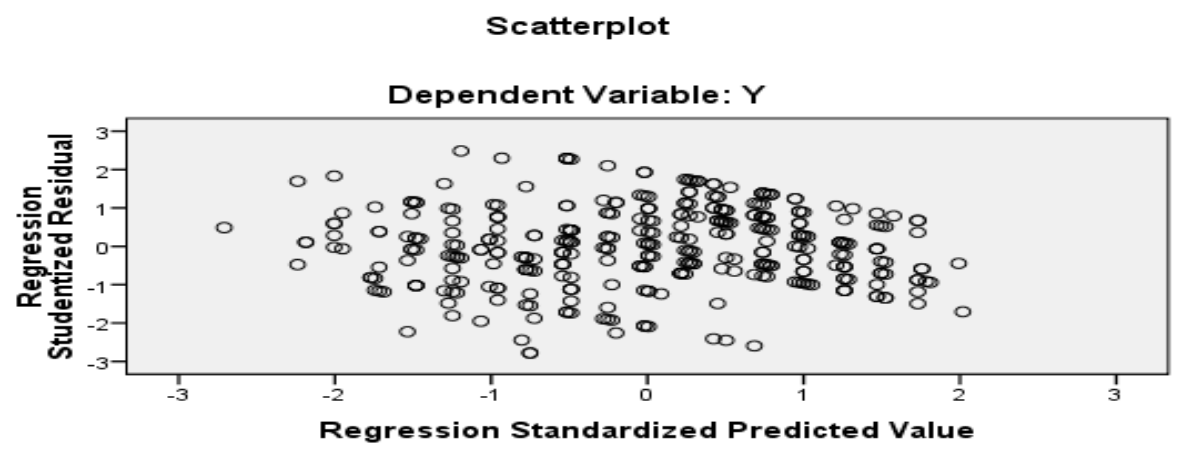

Dari gambar 4.3 diatas terlihat titik-titik yang menyebar secara acak, tidak membentuk suatu pola tertentu yang jelas, serta tersebar baik di atas maupun di bawah angka 0 pada sumbu Y. Sehingga model regresi ini tidak terjadi heteroskedastisitas dan layak dipakaiuntuk memprediksi Pengaruh Struktur Organisasi dan Business Process dan TIK terhadap Kepatuhan Wajib Pajak Orang Pribadi.

Pengujian heteroskedastisitas dapat juga dilakukan dengan uji korelasi spearman antara residual dengan masing-masing variabel independen, dimana variabel independen dalam penelitian ini yaitu Struktur Organisasi, dan Business Process dan TIK, uji heteroskedastisitas dengan spearman yaitu dengan melihat nilai signifikansi antara variabel independen dengan residual.Jika nilai signifikansi antara variabel independen dengan residual lebih dari 0,05 maka dapat disimpulkan tidak terjadi heteroskedastisitas. 
Hasil uji heteroskedastisitas dengan uji korelasi spearman dapat dilihat pada tabel berikut ini:

\section{Tabel Uji Korelasi Spearman \\ Correlations}

\begin{tabular}{|c|c|c|c|c|c|}
\hline & & & Unstandardized Residual & $\mathrm{X} 1$ & $\mathrm{X} 2$ \\
\hline \multirow[t]{9}{*}{ Spearman's rho } & $\begin{array}{l}\text { Unstandardized } \\
\text { Residual }\end{array}$ & Correlation Coefficient & 1,000 & $0,00 \overline{2}^{-}$ & 0,019 \\
\hline & & Sig. (2-tailed) & . & 0,968 & 0,712 \\
\hline & & $\mathrm{N}$ & 366 & 366 & 366 \\
\hline & $\mathrm{X} 1$ & Correlation Coefficient & $-0,002$ & 1,000 & $-0,505^{\star \star}$ \\
\hline & & Sig. (2-tailed) & 0,968 & . & 0,000 \\
\hline & & $\mathrm{N}$ & 366 & 366 & 366 \\
\hline & $\mathrm{X} 2$ & Correlation Coefficient & 0,019 & $0,505^{*}$ & 1,000 \\
\hline & & Sig. (2-tailed) & 0,712 & 0,000 & . \\
\hline & & $\mathrm{N}$ & 366 & 366 & 366 \\
\hline
\end{tabular}

**. Correlation is significant at the 0.01 level (2-tailed).

Sumber : Hasil Pengolahan Data

Hasil uji korelasi spearman pada tabel4.12 diatas menunjukkan bahwa semua variabel independen yaitu Struktur Organisasi, dan Business Process dan TIK mempunyai nilai signifikansi residual lebih dari 0,05. Berdasarkan hasil tersebut maka dapat disimpulkan tidak terjadi heteroskedastisitas.

d. Uji Multikolinearitas

Uji multikoleniertias bertujuan untuk menguji apakah model regresi ditemukan adanya kolerasi antar variabel bebas (independen) (Imam Ghozali, 2012: 105).Pengujian multikolinearitas digunakan untuk menunjukkan apakah ada korelasi diantara variabel independen.Penelitian yang menggunakan teknik analisis regresi bergandaantar variabel independen tidak boleh saling berkorelasi atau terjadi multikolinearitas. Deteksi tidak terjadinya multikolinearitas dapat dilihat pada collinearity statistics dengan ketentuan apabila nilai tolerance value masingmasing variabel independen berada diatas 0,1 dan variance inflation factor atau nilai VIF masing-masing variabel independen berada di bawah 10 maka tidak terjadi multikolinearitas. Hasil uji multikolinearitas dapat dilihat hasilnya sebagai berikut :

Tabel Hasil Uji Multikolinearitas

\begin{tabular}{cccc}
\hline Variabel & \multicolumn{2}{c}{ Collinearity Statistics } & \multirow{2}{*}{ Keterangan } \\
& Tolerance & VIF & \\
\hline Struktur Organisasi (X1) & 0,754 & 1,326 & Tidak ada Multikolinearitas \\
Business Proces dan TIK (X2) & 0,754 & 1,326 & Tidak adaMultikolinearitas \\
\hline
\end{tabular}

Sumber : Data diolah dengan IBM SPSS 20, 2011

Berdasarkan table diatas hasil pengujian multikolinearitas menunjukkan bahwa antar variabel independen Struktur Organisasi dan Business Process dan TIK semuanya tidak terjadi multikolinearitas karena nilai tolerance masing-masing variabel 
independen berada di atas 0,1 dan nilai VIF masing-masing variabel independen berada di bawah 10 .

4. Uji Regresi Linier Berganda

Analisis statistik yang digunakan dalam penelitian ini adalah regresi linier berganda.Analisis ini digunakan untuk mengetahui besarnya pengaruh variabelvariabel bebas (independent) yaitu Struktur Organisasi dan Business Process dan TIK terhadap Kepatuhan Wajib Pajak Orang Pribadi.Besarnya pengaruh variabel independent dengan variabel dependent secara bersama-sama dapat dihitung melalui suatu persamaan regresi berganda.

\section{Tabel Uji Regresi Berganda}

Coefficients $^{a}$

\begin{tabular}{lrr}
\hline \multicolumn{2}{c}{ Model } & \multicolumn{2}{c}{ Unstandardized Coefficients } \\
& B & \multicolumn{2}{c}{ Std. Error } \\
\hline 1 (Constant) & 18,870 & 1,594 \\
X1 & $-0,612$ & 0,082 \\
X2 & 0,549 & 0,087 \\
\hline
\end{tabular}

a. Dependent Variable: $Y$

Berdasarkan Tabel maka Persamaan regresi dalam penelitian ini adalah:

$$
Y=a+b_{1} X_{1}+b_{2} X_{2}
$$

Dimana: $\quad Y=$ Kepatuhan Wajib pajak

$\mathrm{X}_{1}=$ Struktur Organisasi

$\mathrm{X}_{2}=$ Business Process dan TIK

$\mathrm{a}=$ Konstanta

$\mathrm{b}=$ Koefisien Regresi

$$
Y^{\prime}=18,870+-0,612 X_{1}+0,549 X_{2}
$$

Dari persamaan tersebut, dapat diidentifikasikan beberapa hal sebagai berikut:

a. Nilai konstanta $b_{0}=18,870$

Artinya jika Struktur Organisasi $\left(\mathrm{X}_{1}\right)$, dan Business Process dan TIK $\left(\mathrm{X}_{2}\right)$ maka Kepatuhan Wajib Pajak Orang Pribadi (Y) nilainya sebesar 18,870.

b. Nilai koefisienb $=-0,612$

Artinya jika Struktur Organisasi $\left(\mathrm{X}_{1}\right)$ ditingkatkan sebesar 1 satuan, maka akan menurunkan Kepatuhan Wajib Pajak Orang Pribadi (Y) sebesar 0,612 satuan.

c. Nilai koefisien $\mathrm{b}_{2}=0,549$

Artinya jika Business Process dan TIK $\left(\mathrm{X}_{2}\right)$ ditingkatkan sebesar 1 satuan, maka akan meningkatkan Kepatuhan Wajib Pajak Orang Pribadi (Y) sebesar 0,549 satuan.

5. Uji Hipotesis

a) Koefisien Determinasi $\left(\mathrm{R}^{2}\right)$

Nilai koefisien determinasi adalah antara 0 dan 1 . Nilai $R^{2}$ yang kecil berarti kemampuan variabel-variabel independen dalam menjelaskan variasi variabel dependen amat terbatas. Nilai yang mendekati satu berarti variabel-variabel independen memberikan hampir semua informasi yang dibutuhkan untuk memprediksi variasi variabel dependen.Koefisien determinasi yang digunakan adalah nilai Adjusted $R$ square karena lebih dapat dipercaya dalam mengevaluasi model regresi. 
Tabel Hasil Uji $\mathbf{R}^{2}$

Model Summary

\begin{tabular}{|c|c|c|c|}
\hline Model & $\mathrm{R}$ & R Square & Adjusted R Square \\
\hline 1 & $0,585^{\mathrm{a}}$ & 0,343 & 0,339 \\
\hline
\end{tabular}

Berdasarkan Tabel diatas dapat diketahuinilai koefisien determinasi yang disesuaikan (Adjusted $R$ Square) adalah 0,339. Jadi sumbangan pengaruh dari variabel independen yaitu $33,9 \%$ sedangkan sisanya sebesar $66,1 \%$ dipengaruhi faktor lain yang tidak diteliti.

b) Uji Signifikansi Parsial (t-test)

Uji t digunakan untuk menguji pengaruh variabel independen secara parsial terhadap variabel dependen. Dimana pengambilan keputusan disini yaitu :

1) $t_{\text {hitung }} \leq t_{\text {tabel }}$ atau $t_{\text {hitung }} \geq t_{\text {tabel }}$ jadi $\mathrm{H}_{0}$ diterima.

2) $t_{\text {hitung }}>t$ tabel atau $t_{\text {hitung }}<t$ tabel jadi $\mathrm{H}_{0}$ ditolak

3) Pengambilan signifikansi $>0,05$ jadi $\mathrm{H}_{0}$ diterima, dan jika signifikansi $\leq 0,05$ jadi $\mathrm{H}_{0}$ ditolak.

Berdasarkan hasil pengolahan dengan program SPSS IBM 20.0 maka didapat hasil uji statistik t sebagai berikut:

\section{Tabel Uji T}

Coefficients $^{\mathbf{a}}$

\begin{tabular}{lrrrrr}
\hline \multirow{2}{*}{ Model } & \multicolumn{2}{c}{$\begin{array}{l}\text { Unstandardized } \\
\text { Coefficients }\end{array}$} & \multicolumn{2}{c}{$\begin{array}{c}\text { Standardized } \\
\text { Coefficients t }\end{array}$} & Sig. \\
& B & Std. Error & Beta & & \\
\hline (Constant) & 18,870 & 1,594 & & 11,839 & 0,000 \\
X1 & $-0,612$ & 0,082 & 0,366 & $-7,476$ & 0,000 \\
X2 & 0,549 & 0,087 & 0,310 & 6,321 & 0,000 \\
\hline
\end{tabular}

a. Dependent Variable: Y

Berdasarkan hasil pengolahan data diatas, menunjukkan bahwa koefisien regresi variabel independen yaitu Struktur Organisasi (X1) mempunyai koefisien regresi sebesar 0,366 dengan nilai signifikansi sebesar 0,000. Nilai signifikansi ini kurang dari nilai taraf signifikansi yaitu 0,05 . Nilai $t_{\text {hitung }}$ berdasarkan hasil pengolahan data di atas adalah sebesar -7,476, sedangkan $t_{\text {tabel }}$ sebesar 1,966. Maka dapat disimpulkan bahwa $t_{\text {hitung }}$ lebih besar dari $t_{\text {tabel }}(-7,476>1,966)$. Hal ini berarti bahwa Struktur Organisasi berpengaruh signifikan terhadap Kepatuhan Wajib Pajak Orang Pribadi (Y). Maka Ha $\mathrm{Ha}_{1}$ diterima.

Hasil uji regresi menunjukkan bahwa variabel independen yaitu Business Process dan TIK $\left(\mathrm{X}_{2}\right)$ sebesar 0,310 dengan nilai signifikansi sebesar 0,000. Nilai signifikansi ini lebih kecil dari nilai taraf signifikansi yaitu 0,05. Nilai $t_{\text {hitung }}$ berdasarkan hasil pengolahan data di atas adalah sebesar 6,321 sedangkan $t_{\text {tabel }}$ sebesar 1,966. Maka dapat disimpulkan bahwa $t_{\text {hitung }}$ lebih besar dari $t_{\text {tabel }}$ $(6,321>1,966)$. Hal ini berarti bahwa Business Process dan TIK $\left(\mathrm{X}_{2}\right)$ berpengaruh signifikan terhadap Kepatuhan Wajib Pajak Orang Pribadi (Y). Maka Ha 2 diterima. 
c) Uji Signifikansi Simultan (F test)

Uji $F$ digunakan untuk menguji pengaruh variabel independen secara bersama-sama terhadap variabel dependen. Pengujiannya sebagai berikut :

1) Dimana $F_{\text {hitung }}>\mathrm{F}_{\text {tabel}}$, maka $\mathrm{H}_{3}$ diterima atau secara bersama-sama variabel bebas dapat menerangkan variabel terikatnya secara serentak.

2) Apabila $F_{\text {hitung }}<\mathrm{F}_{\text {tabel}}$, maka $\mathrm{H}_{0}$ diterima atau secara bersama-sama variabel bebas tidak memiliki pengaruh terhadap variabel terikat. Untuk mengetahui signifikan atau tidak pengaruh secara bersama-sama variabel bebas terhadap variabel terikat maka digunkan probability sebesar $5 \%(\alpha=0,05)$. Jika sig $>\alpha$ $(0,05)$, maka $\mathrm{H}_{0}$ diterima $\mathrm{H}_{3}$ ditolak. Jika sig $<\alpha(0,05)$, maka $\mathrm{H}_{0}$ ditolak $\mathrm{H}_{3}$ diterima. Berdasarkan hasil pengolahan dengan program SPSS 20 maka di dapat hasil uji F :

\section{Tabel Hasil Uji F}

ANOVA ${ }^{b}$

\begin{tabular}{lrrrrr}
\hline Model & Sum of Squares & Df & Mean Square & F & \multicolumn{1}{c}{ Sig. } \\
\hline Regression & 2000,623 & 2 & 1000,311 & 94,634 & $0,000^{\mathrm{a}}$ \\
Residual & 3837,006 & 363 & 10,570 & & \\
Total & 5837,628 & 365 & & & \\
\hline
\end{tabular}

a. Predictors: (Constant), X2, X1

b. Dependent Variable: Y

Berdasarkan hasil uji statistik $\mathrm{F}$ pada tabel 4.17 diatas nilai $\mathrm{F}$ sebesar 96,634 dengan probabilitas signifikansi yang menunjukkan nilai 0,000 . Nilai probabilitas signifikansi ini lebih kecil dari nilai taraf signifikansi yaitu 0,05. Berdasarkan hasil pengolahan data di atas nilai $F_{\text {hitung }}$ sebesar 96,634 sedangkan $F_{\text {tabel }}$ sebesar 2,40. Maka dapat disimpulkan bahwa $F_{\text {hitung }}$ lebih besar dari $F_{\text {tabel }}(96,634>2,40)$. Hal tersebut menunjukkan hasil bahwa $\mathrm{H}_{\mathrm{a}}$ diterima. Maka dapat disimpulkan variabel Struktur Organisasi dan Business Process dan TIK, berpengaruh signifikan terhadap Kepatuhan Wajib Pajak Orang Pribadi (Y). Maka $\mathrm{Ha}_{3}$ diterima.

\section{PEMBAHASAN}

Berikut ini adalah pembahasan hasil penelitian dari pengaruh Struktur Organisasi $\left(\mathrm{X}_{1}\right)$, dan Business Process dan TIK $\left(\mathrm{X}_{2}\right)$ terhadap Kepatuhan Wajib Pajak Orang Pribadi (Y).

1. Pengaruh Struktur Organisasiterhadap Kepatuhan Wajib Pajak Orang Pribadi.

Hipotesis alternatif 1 bertujuan untuk menguji PengaruhStruktur Organisasiterhadap Kepatuhan Wajib Pajak Orang Pribadi.Hal ini menunjukkan bahwa Struktur Organisasi berpengaruh negatif signifikan terhadapKepatuhan Wajib Pajak Orang Pribadi. Maka hipotesis alternatif 1 diterima. Nilai koefisien negatif berarti terdapat hubungan berbanding terbalik, semakin baik perubahan Struktur Organisasi maka semakin rendah Kepatuhan Wajib Pajak Orang Pribadi. Karena dengan melebur jadi satu anatara (1) Kantor Pelayanan Pajak (KPP), (2) Kantor Pelayanan Pajak Bumi dan Bangunan (KPPBB), (3) Kantor Pemeriksaan dan Penyidikan Pajak (Karikpa) menjadi Kantor Pelayanan Pajak (KPP) Madiun, maka kurang memudahkan jalur penyelesaian pelayanan dan pemeriksaan wajib pajak. Account Representative yaitu membimbing wajib pajak dalam melaksanakan kewajiban perpajakannya, memberikan bantuan konsultasi perpajakan kepada wajib pajakdan menginformasikan peraturan perpajakan yang baru serta mengawasi 
Kepatuhan Wajib Pajak. Tetapi kenyataannya berbalik arah yaitu petugas Account Representative kurang efektif menjalankan fungsinya sebagaimana mestinya yaitu melayani dan memberikan bantuan konsultasi perpajakan kepada Wajib Pajak dalam menyelesaikan permasalahannya mengenai Kewajiban Perpajakannya secara tuntas.

2. PengaruhBusiness Process dan TIK terhadap Kepatuhan Wajib Pajak Orang Pribadi.

Pengujian hipotesis alternatif kedua bertujuan untuk menguji pengaruh Business Process dan TIK terhadap Kepatuhan Wajib Pajak Orang Pribadi. Hasil analisis data menunjukkan bahwa koefisien regresi variabel independen yaitu Business Process dan TIK berpengaruh signifikan terhadap Kepatuhan Wajib Pajak Orang Pribadi. Hasil penelitian ini menunjukkan bahwa Perbaikan Business Process dan TIK berpengaruh signifikan terhadap kepatuhan wajib pajak. Dari banyaknya jawaban responden Business Process dilakukan untuk menyederhanakan proses pengawasan serta mempercepat proses pengambilan keputusan secara efisien dan efektif. Perbaikan proses bisnis juga dilakukan antara lain dengan memanfaatkan Teknologi Informasi dan Komunikasi dengan dibukanya fasilitas e-filling (pengiriman SPT secara online melalui internet), e-payment (modul penerimaan negara) dan e-regristration (pendaftaran NPWP secara Online melalui internet). Semua fasilitas tersebut disediakan untuk memberikan kemudahan bagi Wajib Pajak dalam melaksanakan kewajiban perpajakannya tanpa terkendala selama 24 jam sehari dan 7 hari seminggu termasuk hari libur, maka Business Process mampu meningkatkan Kepatuhan Wajib Pajak Orang Pribadi.

3. Pengaruh Struktur Organisasi, Business Process dan TIK, terhadap Kepatuhan Wajib Pajak Orang Pribadi.

Pengujian hipotesis alternatif kelima bertujuan untuk menguji pengaruh variabel Struktur Organisasi dan Business Process dan TIK berpengaruh signifikan terhadapKepatuhan Wajib Pajak Orang Pribadi. Berdasarkan hasil pengolahan data di atas maka dapat disimpulkan bahwa $F_{\text {hitung }}$ lebih besar dari $F_{\text {tabel }}(94,634>2,40)$. Hal tersebut menunjukkan hasil bahwa $\mathrm{H}_{\mathrm{a} 3}$ diterima yaitu Struktur Organisasi dan Business Process dan TIk secara simultan berpengaruh terhadap Kepatuhan Wajib Pajak Orang Pribadi.

\section{KETERBATASAN}

Penelitian ini memiliki beberapa keterbatasan yang dapat mempengaruhi hasil penelitian yaitu:

1. Penelitian ini hanya menggunakan dua variabel independen yaitu Struktur Organisasi dan Business Process dan TIK sehingga ada kemungkinan terdapat variabel lain diluar variabel penelitian yang juga berpengaruh terhadap Kepatuhan Wajib Pajak Orang Pribadi contohnya Budaya Organisasi, Kode Etik dan Kualitas Layanan.

2. Penelitian ini hanya dilakukan pada Wajib Pajak Orang Pribadi Tahun 2013 sejumlah 30.743 orang di Wilayah Kota Madiun yang Terdaftar pada Kantor Pelayanan Pajak (KPP) Pratama Madiun.

\section{SARAN}

Adapun beberapa saran yang dapat disampaikan berdasarkan kesimpulan dari hasil penelitian ini adalah:

1) Bagi KPP Pratama Madiun

Dengan adanya Struktur Organisasiterhadap Kepatuhan Wajib pajak seharusnya petugas Account Representative menjalankan fungsinya sebagaimana mestinya yaitu melayani dan memberikan bantuan konsultasi perpajakan kepada 
Wajib Pajak dalam menyelesaikan permasalahannya mengenai Kewajiban Perpajakannya secara tuntas.

2) Peneliti Selanjutnya

a) Diharapkan agar peneliti selanjutnya meneliti lebih lanjut mengenaifaktor-faktor lain yaitu Strategi Organisasi, Budaya Organisasi dan Prosedur Organisasi yang memiliki pengaruh terhadap Kepatuhan Wajib Pajak.

b) Disarankan jika ingin meneliti mengenai Kepatuhan Wajib Pajak sebaiknya meneliti di seksi pemeriksaan karena untuk mengetahui Kepatuhan Wajib Pajak akan lebih tepat jika dikaitkan dengan aktivitas pemeriksaan.

3) Bagi Wajib Pajak

Seiring berjalanya sistem administrasi perpajakan modern maka diharapkan wajib pajak lebih patuh dalam pembayaran pajak karena dengan adanya fasilitas teknologi yang disediakan oleh Direktorat Jendral Pajak, seperti $e$-SPT, e-filing, $e$ registration semua fasilitas tersebut disediakan untuk lebih memudahkan wajib pajak dalam melaksanakan kewajiban perpajakannya.

\section{DAFTAR PUSTAKA}

Departemen Keuangan Republik Indonesia. 2007. Modernisasi Administrasi Perpajakan. Jakarta: Direktorat Jendral Pajak.

Djoko Muljono. 2010. Hukum Pajak Konsep, Aplikasi, dan Penuntun Praktis. Yogyakarta: Andi.

Duwi Priyatno.2010. Teknik Mudah dan Cepat Melakukan Analisis Data Penelitian Dengan SPSS dan Tanya Jawab Ujian Pendadaran. Yogyakarta: Gava Media.

Harry Purwono. 2010. Dasar-dasar Perpajakan dan Akuntansi Pajak. Jakarta: Erlangga.

Haula Rosdianan dan Edi Slamet Irianto. 2011. Panduan Lengkap Tata Cara Perpajakan Indonesia, Cetakan Pertama, Jakarta Selatan, Visimedia.

Imam Gozali. 2011. Aplikasi Analisis Multivariate denganProgram SPSS, Cetakan ketuju, Badan penerbit Universitas Diponegoro, Semarang.

Mardiasmo. 2011. Perpajakan Edisi Revisi 2011. Yogyakarta: Andi.

Mohammad Zain. 2007. Manajemen Perpajakan, Edisi 3, Jakarta, Salemba Empat.

Pika Nopikasari. 2013. "Pengaruh Penerapan Modernisasi Administrasi Perpajakan terhadap Kepatuhan Wajib Pajak Badan (Survey pada Wajib Pajak Badan Berbentuk PT yang Terdaftar Pada Kantor Pelayanan Pajak (KPP) Pratama Tasikmalaya)", http://www.search.ask.com/web=jurnal + pengaruh + penerapan + modernisas + adminis trasi + perpajakan + terhadap + kepatuha + wajib + pajak + badan \&page $=4 \&$ ots $=1399296$ 891121. Diunduh 5Agustus 2014.

Ricki Candra, Haris Wibisono, Mujilan. 2013. "Modernisasi Sistem Administrasi Perpajakan dan Kepatuhan Wajib Pajak", Vol.1 No. http://portal.widyamandala.ac.id/jurnal/index.php/jrma/artide/view/91. Diunduh 15 September 2014.

Rusman, Deni Kurniawan, Cepi Riyana. 2012. Pembelajaran Berbasis Teknologi Informasi dan Komunikasi: Mengembangkan Profesionalitas Guru. Jakarta: Rajawali Pers.

Sigit Hutomo. 2009. Pajak Penghasilan: Konsep dan Aplikasi (Edisi Revisi). Yogyakarta: Universitas Atmajaya Yogyakarta.

Sri Rahayu dan Lingga, Ita Salsalina. 2009. "Pengaruh Modernisasi Sistem Administrasi Perpajakan terhadap Kepatuhan Wajib Pajak", Vol.1 No.2, majour.maranatha.edu/index.php/jurnal-akuntansi/article/.../pdf. Diunduh 15 Maret 2014.

Siti Resmi. 2013. Perpajakan: Teori dan Kasus. Jakarta: Salemba Empat. 
Sugiyono. 2010. Metode Penelitian Pendidikan: Pendekatan Kuantitatif, Kualitatif dan R\&D. Bandung: Alfabeta.

Thomas Sumarsan. 2013. Pedoman Perpajakan yang Lengkap Berdasarkan Undang-undang Terbaru. Jakarta Barat: PT Indeks.

Waluyo. 2011. Perpajakan Indonesia, Edisi 9. Jakarta: Salemba Empat.

Widi Widodo, Deddy Djefris, dan Eka A.W. 2010. Moralitas,Budaya, dan Kepatuhan Pajak. Bandung: Alfabeta. 